\title{
EFFECT OF USING SOME FIBROLYTIC ENZYMES IN THE RATION ON LACTATING GOATS PERFORMANC
}

\author{
G.E. Aboul-Fotouh ${ }^{1}$, G.M. El-Garhy ${ }^{1}$, A.M. Abd El-Mola ${ }^{1}$, G.A. Mousa' ${ }^{1}$ and H.H. Azzaz ${ }^{2}$ \\ ${ }^{1}$ Animal Production Department, Faculty of Agriculture, Fayoum University, Egypt. \\ ${ }^{2}$ Dairy Department, National Research Centre, Buhouth St, Dokki, Giza, Egypt.
}

\section{SUMMARY}

$\mathrm{T}$ The present study was carried out at farm and laboratory of Animal Production Department- Faculty of Agriculture, Fayoum University, Egypt. Fibrolytic enzymes were evaluated throughexperiments conducted by using nine of lactating baladi goats after 20 days of parturition and divided into three groups, three animals per each group. The first group was fed 50\% concentrate feed mixture , $10 \%$ Egyptian clover and $40 \%$ wheat straw (Control ration). The second group was fed control ration supplemented with Asperozym(locally produced cellulase enzyme) at level of 1000 unit of cellulase enzyme /kg DM intake (R1). The third group was fed control ration supplemented with Phytabex plus ${ }^{\circledR}$ (commercial cellulolytic enzyme source ) at level of 1000 unit of cellulolytic enzymes / $\mathrm{kg} \mathrm{DM}$ intake. (R2 ). The results revealed that Asperozym was superior to Phytabex plus ${ }^{\circledR}$ for improving feed digestion and milk production by goats.. There were significant $(\mathrm{P} \leq 0.05$ ) increases in fat corrected milk yield ( $4 \%$ fat) and fat percentage of ( R1) and ( R2 ) compared to control ration. Feed conversion of DM, SV and TDN was decreased significantly $(\mathrm{P} \leq 0.05)$ with control ration compared to $\mathrm{R} 1$ and $\mathrm{R} 2$ rations. Results of some blood serum analysis showed that no side effect of using the tested cellulolytic enzymes on lactating goats. From economical point of view, the best ration was R1.

Keywords: cellulase enzyme, digestibility, milk yield and its composition, lactating goats.

\section{INTRODUCTION}

The problems of feeding roughage directly to farm animals are in general, low protein content, high crude fiber, low digestibility coefficients and containing some anti-nutrients factors such as tannins and alkaloids (Kholifet al., 2005). Thus, to increase digestibility of these crop residues, it is important to destroy the compact nature of this lignocellulosic tissues and reduce the deleterious effects of the antinutrients factors.There are main reasons for using enzymes as livestock feed supplements: 1) to break down anti-nutritional factors; 2) to increase the availability of starches, proteins and minerals enclosed within fiber-rich cell walls; and 3) to break down specific chemical bounds in raw materials which are not usually broken down by the animals' own enzymes (Sheppy, 2001).Many researchers demonstrated that, supplementing rations of dairy animals with fibrolytic enzymes can improve feed utilization and animal performance by enhancing fiber degradation in vitro (Gadoet al., 2009, Rodrigues et al., 2008 and Azzazet al, 2012).

Addition of exogenous enzymes to animal rations can improve feeding values by increasing feed intake and improving fibre degradation (Salem et al., 2015 and Valdes et al., 2015). Some studies showed that enzyme addition increased nutrient digestibility and increased milk production of dairy animals (Khattabet al., 2011, Kholifet al., 2012, , Salem et al., 2015, Silva et al., 2016, and Upadhayaet al., 2016), but others showed only weak effects on animal performance (Ballard et al. 2003and Reddish and Kung, 2007). Therefore, this study was carried out to investigating the impact of adding these enzymes to lactating goats ration on nutrients digestibility, milk yield and composition, feed conversion and some blood parameters were conducted.Also, simple economical evaluation of the tested rations was considered. 


\section{MATERIALS AND METHODS}

The present study was carried out at farm and laboratory of Animal Production Department, Faculty of Agriculture, Fayoum University, Egypt.

Enzyme source:Asperozym,(local cellulase enzyme) waslaboratory produced by Aboul Fotouhet al .(2016) from Asperigillusnigerand each (g) of it contains 240 cellulase units.Phytabex plus $^{\circledR}$ 'a commercial cellulolytic enzyme source produced by EN BIO. TECH CO., LTD - China and purchased from the company of IBEX International LTD (United Kingdom). Each (g) of it contains 500 unit of cellulase.

\section{Digestibility and lactation trials: Experimental animals:}

Nine of lactating baladi goats (in their $2^{\text {th }}$ to $4^{\text {th }}$ lactation seasons) and weighed $20 \pm 1 \mathrm{~kg}$ in average .After 20 days of parturition were randomly assigned into three groups, three animals per each tested ration $(\mathrm{R})$ using complete randomized design. The experimental period was 45 days.

The tested rations:

The goats were individually fed rations of concentrate: roughage at ratio of 1:1 on DM basis. The first animal group was fed on ration of $50 \%$ concentrate feed mixture (CFM), 10\% Egyptian clover and $40 \%$ wheat straw (Control ration).The two cellulase enzymes were supplemented to the rations at the optimum rate which recommended from the in vitro experiment (Aboul - Fotouhet al .,2016 1.Where,the second group ( R1) was fed control ration supplemented with Asperozym at 1000 unit of cellulase enzyme/kg DM, while the third group ( R2) was fed control ration supplemented with Phyabex plus ${ }^{\circledR}$ (Commericial enzyme) at 1000 unit of cellulolytic enzymes $/ \mathrm{kg} \mathrm{DM}$.Animals were fed to cover their nutritional requirements according to N.R.C (1985). The compositionof tested rationsare shown in Table (1).

Table (1): Composition of the tested rations of lactating goats (on DM basis).

\begin{tabular}{lccc}
\hline & \multicolumn{2}{c}{ The tested rations } \\
\cline { 2 - 4 } Item & Control & $\mathrm{R} 1$ & $\mathrm{R} 2$ \\
\hline Concentrate feed mixture & 50 & 50 & 50 \\
Wheat straw & 40 & 40 & 40 \\
Egyptian clover & 10 & 10 & 10 \\
& & 1000 unit of & 1000 unit of phytabex plus $\left({ }^{2} / \mathrm{kg}\right.$ \\
Cellulase enzyme & ---- & Asperozym $/ \mathrm{kg} \mathrm{DM}$ & DM \\
\hline
\end{tabular}

Formulation of concentrates feed mixture on DM basis was 55\% yellow Corn , 21.5\% wheat bran, $20 \%$ soya bean meal , 3.5\% feed Additives (feed additives composed of $1.5 \%$ limestone, $0.5 \%$ dicalcium phosphate, $0.2 \%$ yeast, $0.3 \%$ bicarbonate, $0.5 \%$ premix and $0.5 \% \mathrm{NaCl}$.)

\section{Digestibility trial:-}

Digestibility trial was performed at the end of the lactation experiment, the nutrient digestibilities and feeding values were determined using acid insoluble ash (AIA) technique of VanKeulen and Young (1977). Feces samples were collected daily per each animal for seven days, dried over night at $60{ }^{\circ} \mathrm{C}$ in hot air oven, weighted, ground through $1 \mathrm{~mm}$ screen, then complete drying was undertaken at $105{ }^{\circ} \mathrm{C}$ for 3 hrs and weighted and stored in tight bottles for chemical analysis.

\section{Milk yield:}

The technique of hand milking was used to estimate milk yield. Goats have been milked twice daily at 6:00 am and 6:00 pm by milking one teat while, the other one was lift to lamb for suckling according to Farag (1979). Daily milk yield and Total milk yield were recorded for each animal in the experiment for two weeks after preliminary period (24 days). 


\section{Methods of analysis:}

\section{Feeds and feces analysis}

Chemical analysis of feed stuffs and feces samples were carried out according to methods ofA.O.A.C . (1995).the nitrogen free extract (NFE) was calculated by difference. Neutral detergent fiber (NDF), acid detergent fiber (ADF) and acid detergent Lignin (ADL) were determined in feeds and feces according to Goering and Van Soest (1970).

\section{Milk samples and analysis:}

Daily milk samples (50 ml each) were collected at 6:00 am and 6:00 pm and mixed for each animal in the experiment. It were kept frozen at $(-20 \mathrm{C})$ until the chemical analysis were executed. Milk composition were determined by Ekomilk ${ }^{\circledR}$ analyzer (KAM98-2A USA).

Fat corrected milk (4\% FCM) was calculated by using the following equation according to Gaines (1928).

Blood samples: Blood samples were collected before starting of lactation trial and at the end of the experiment before morning feeding. Serum urea was measured according to Richard et al. (2011). Serum glucose (SG) was measured according to Howanitz and Howantiz (1984).Serum creatinine was measured according to Spiertoet al. (1979).Total cholesterol was quantified by colorimetric method according to Burtiset al. (2006).Serum aspartate aminotransferase (AST) and alaninaminotransferase (ALT) were determined by using test kits according to Reitman andFrankel (1957).

\section{Statistical analysis:}

Statistical analyses were conducted by the general linear model procedure adapted by SPSS (2007) according to the following model: $Y_{i j}=\mu+T_{i}+e_{i j}$ Where $Y_{i j}$ is the dependent variable, $\boldsymbol{\mu}$ is the overall mean, $T_{i}$, is the effect of treatment and $e_{i j}$ is the residual error. Duncan's multiple test (Duncan, 1955) was carried out to separate among means.

\section{Simple economical evaluation:}

Economical returns of the tested rations were calculated at the time of the experiment (May, 2016) assuming that the price of one $\mathrm{kg}$ of raw milk was 9 L.E. The cost of one ton DM of CFM , Egyptian clover and wheat straw were 2800, 250 and 800 L.E., respectively.Also price of one $\mathrm{kg}$ of Asperozym was 50 L.E.and price of one $\mathrm{kg}$ of phytabex plus ${ }^{\circledR}$ was 200 L.E.

\section{RESULTS AND DISCUSSION}

Chemical composition of feed ingredients: The chemical composition and cell wall constituents (DM basis) feed ingredients are shown in Table (2). The chemical composition indicated a comparable DM composition of all ingredients. Wheat straw showed the highest levels of crude fiber and ash content and lower content of CP compared toEgyptian clover and concentrate feed mixture. Also, wheat straw showed higher levels of NDF and cellulose contents compared to other feed ingredients.

Digestibility and nutritive values: Data of Table (3) clearly show that, both of rations supplemented with Asperozym $\left(\mathrm{R}_{1}\right)$ and Phytabex plus ${ }^{\circledR}\left(\mathrm{R}_{2}\right)$ significantly $(\mathrm{P} \leq 0.05)$ increased $\mathrm{DM}, \mathrm{OM}$ and $\mathrm{CF}$ digestibility compared to the control ration. Ration supplemented withAsperozym $\left(\mathrm{R}_{1}\right)$ was superior significantly $(\mathrm{P} \leq 0.05)$ to control ration regarding NFE digestibility. On the other hand, no significant differences were found between Asperozym and phytabex plus rations concerning $\mathrm{OM}, \mathrm{CP}, \mathrm{CF}$ and $\mathrm{EE}$ digestibilties.

Such findings are in favor with other studies which reported increase in total tract digestibility of DM and OM, following treatment with fibrolytic enzymes (Gado et al., 2009, Azzaz et al., 2012, Kholif et al., 2012, Salem et al., 2015, Aguirre et al., 2016, Silva et al.,2016, Morsyet al., 2016 and Upadhaya et al., 2016).

Exogenous fibrolytic enzymes would be expected to increase total tract digestibility by increasing the rate of ruminal digestion of the potentially digestible NDF fraction (Yang et al., 1999).

The nutritive values of the experimental rations are shown in Table (3).Ration supplemented with Asperozym $\left(\mathrm{R}_{1}\right)$ significantly $(\mathrm{P} \leq 0.05)$ increased SV \% compared to control ration. Ration supplemented with Phytabex plus ${ }^{\circledR}\left(\mathrm{R}_{2}\right)$ increased SV\% but not significantly differences was found with control ration. 
Table (2): Chemical composition of feed ingredients (on \% DM basis).

\begin{tabular}{lccc}
\hline Item & CFM & wheat straw & Egyptian clover \\
\hline & \multicolumn{2}{c}{ Chemical composition, \% } \\
OM & 96.64 & 82.57 & 83.8 \\
CP & 16.73 & 3.84 & 17.67 \\
EE & 4.86 & 0.66 & 1.64 \\
CF & 4.83 & 42.52 & 25.77 \\
NFE & 70.22 & 35.55 & 38.72 \\
Ash & 3.36 & 17.43 & 6.97 \\
& \multicolumn{2}{c}{ Cell wall constituents, \% } & 38.86 \\
NDF & 16.13 & 69 & 17.92 \\
ADF & 5.54 & 54 & 4.96 \\
ADL & 0.86 & 20.3 & 20.94 \\
Hemicellulose & 10.59 & 15 & 12.96 \\
Cellulose & 4.68 & 33.7 & \\
\hline
\end{tabular}

Hemicellulose $=N D F-A D F$, Cellulose $=A D F-A D L, C F M:$ concentrate feed mixture

Table (3): Effect of Cellulolytic enzymes on digestion coefficients and nutritive values of the tested rations fed to goats.

\begin{tabular}{|c|c|c|c|c|}
\hline Item & Control & $\mathrm{R} 1$ & $\mathrm{R} 2$ & $\pm \mathrm{SE}$ \\
\hline \multicolumn{5}{|c|}{ Nutrient digestibilities (\%) } \\
\hline DM & $63.69^{\mathrm{c}}$ & $67.01^{\mathrm{a}}$ & $65.89^{\mathrm{b}}$ & 0.67 \\
\hline $\mathrm{OM}$ & $68.52^{b}$ & $72.63^{\mathrm{a}}$ & $71.53^{\mathrm{a}}$ & 0.86 \\
\hline $\mathrm{CP}$ & 61.07 & 62.61 & 61.91 & 1.47 \\
\hline $\mathrm{CF}$ & $64.42^{\mathrm{b}}$ & $67.74^{\mathrm{a}}$ & $68.36^{\mathrm{a}}$ & 0.70 \\
\hline $\mathrm{EE}$ & 68.98 & 71.52 & 70.00 & 0.76 \\
\hline NFE & $73.30^{\mathrm{b}}$ & $76.25^{\mathrm{a}}$ & $74.93^{a b}$ & 0.58 \\
\hline \multicolumn{5}{|c|}{ Nutritive values: } \\
\hline TDN (\%) & $65.73 \mathrm{~b}$ & 68.74 & 67.63 & 0.78 \\
\hline $\mathrm{SV}(\%)$ & $56.53^{\mathrm{b}}$ & $60.99^{\mathrm{a}}$ & $58.22^{\mathrm{ac}}$ & 0.64 \\
\hline DCP $(\%)$ & 7.13 & 7.67 & 7.23 & 0.17 \\
\hline
\end{tabular}

Average in the same row having different superscripts are differ significantly $(P \leq 0.05)$ for $a, b$ and $c$.

This may be attributed to accumulation of a large amount of readily fermentable carbohydrate which liberated due to action of cellulolytic enzymes on cellulose and pectin of rations. On the other hand, digestible crude protein (DCP) and total digestible nutrients (TDN) of rations supplemented with cellulolytic enzymes were insignificantly higher than control ration. Digestible crude protein (DCP) was not affected by cellulolytic enzymes rations. Our results are in the same trend with those obtained by Knowlton et al. (2002) and Muwalla et al. (2007). They mentioned that, apparent protein digestibility was not significantly affected by fibrolytic enzymes treatment.

\section{Lactating goats performance:}

Milk yield and its composition: Data of Table (4) showed that, there were no significant $(\mathrm{P} \leq 0.05)$ differences among control and cellulolytic enzymes rations in actual milk yield. Control ration recorded the lowest milk yield. Generally, adding Asperozym or phytabex plus® to lactating goats ration increased milk yield and its compositions compared to control ration. Concerning $4 \%$ fat corrected milk, there were significant $(\mathrm{P} \leq 0.05)$ increases in fat corrected milk yield and fat percentage of $(\mathrm{R} 1)$ and $(\mathrm{R} 2)$ compared to control ration. These results confirmed those obtained by Beauchemin et al. (1999) they found that, actual 
milk production was not affected significantly $(\mathrm{P}<0.05)$ by fibrolytic enzyme supplementation; However production of $4 \% \mathrm{FCM}$ tended to be higher $(\mathrm{P}<0.05)$ for cows fed supplemental enzyme than control cows. These findings may reflect the effect of exogenous enzyme which attributed to the larger amount of fibre digested in the rumen to provide more acetate for fatty acid synthesis. On the other hand, Bowman et al. (2002) reported that,despite the increase in total tract feed digestion, the response in milk production was not observed with fibrolytic enzymes supplementation to diets of dairy Holstein cows. Such differences may reflect the effect of animal breed.

Table (4): Effect of cellulolytic enzymes supplemented rations on lactating goat's performance.

\begin{tabular}{lcccc}
\hline Item & \multicolumn{3}{c}{ Rations } & \\
\cline { 2 - 4 } & Control & $\mathrm{R}_{1}$ & $\mathrm{R}_{2}$ & $\pm \mathrm{SE}$ \\
\hline Average actual milk yield (g / head / day). & 339.44 & 385 & 373.3 & 39 \\
Total milk yield (kg / head 45day) / & 15.27 & 17.33 & 16.80 & 2.17 \\
Average 4\% Fat corrected milk yield (g /head /day) & 275.29 & $348.62^{\mathrm{b}}$ & $340.82^{\mathrm{a}}$ & 33.14 \\
& Milk compositions $\%:$ & & & \\
Total solids & 10.84 & 11.66 & 11.48 & 0.93 \\
Fat & $2.74^{\mathrm{b}}$ & $3.37^{\mathrm{a}}$ & $3.42^{\mathrm{a}}$ & 0.12 \\
SNF & 8.10 & 8.29 & 8.06 & 0.11 \\
Total protein & 2.98 & 3.32 & 3.03 & 0.07 \\
Lactose & 4.49 & 4.31 & 4.38 & 0.06 \\
Ash & 0.63 & 0.66 & 0.65 & 0.01 \\
& Average daily feed intake/head: & & \\
DM, kg & 0.743 & 0.756 & 0.757 & 0.21 \\
SV, Kg & 0.42 & 0.46 & 0.44 & 0.04 \\
TDN, kg & 0.49 & 0.52 & 0.51 & 0.11 \\
DCP, g & 52.98 & 57.99 & 54.73 & 0.82 \\
DM/ kg/kg milk & $2.70^{\mathrm{a}}$ & $2.17^{\mathrm{b}}$ & $2.22^{\mathrm{b}}$ & 0.31 \\
SV/ kg/kg milk & $1.53^{\mathrm{a}}$ & $1.32^{\mathrm{b}}$ & $1.29^{\mathrm{b}}$ & 0.18 \\
TDN/ kg/kg milk & $1.78^{\mathrm{a}}$ & $1.49^{\mathrm{b}}$ & $1.50^{\mathrm{b}}$ & 0.23 \\
DCP/g/g milk & 0.19 & 0.17 & 0.16 & 0.08 \\
\hline
\end{tabular}

Average in the same row having different superscripts are differ significantly $(P \leq 0.05)$ for a and $b$. Each value is amean of 3 samples. *, Fed conversion was calculated depend on daily $4 \%$ fat corrected milk.

Feed conversion:Result of daily feed intake in (Table, 4) for lactating goats clearly showed that, no significant differences were found between the tested rations.Peteraet al. (2015) investigated that, no effects observed of exogenous fibrolytic enzymes supplementation on Dry matter intake of dairy cows during different stages of lactation .Results of daily feed conversion in Table (4) for lactating goats clearly showed that, feed conversion of DM, SV and TDN of control ration was significantly $(\mathrm{P} \leq 0.05)$ decreased compared to $\left(R_{1}\right)$ and $\left(R_{2}\right)$ rations .On the other hand, there were no significant differences were detected in feed conversion of DCP between the tested rations. Also, there were insignificant differences between R1 and R2 regarding feed conversion. Azzaz, (2009) found that, diets supplemented with cellulolytic enzymes efficient for feeding than control diet of lactating zaraibi goats.

\section{Some blood serum parameters:}

Effect of the cellulolytic enzymes on serum urea concentration of lactating goats received the tested rations are shown in Table (5). Urea is the principal end product of nitrogen metabolism in ruminants. It is synthesized in the liver and extract in glomerular. The values of serum urea were 30.67, 32.33 and 34 (mg/dl) for control, R1 and $\mathrm{R}_{2}$, respectively

Serum creatinine of lactating goats received the tested rations are shown in Table (5).). There wereno significantdifferences between the tested rations in serum creatinine. Salem et al. (2015) found that, feeding horses a high fiber diet with exogenous fibrolytic enzyme supplementation no effects $(\mathrm{P}<0.05)$ were observed for blood creatinine. 
Aspartate aminotransferase (AST) of lactating goats received the tested rations are shown in Table (5). There were insignificant differences among the rations in the overall means of serum AST. Such finding indicated that, no side effect was found regarding using the tested cellulolytic enzymes in lactating goats rations. Azzaz et al. (2012) found that, insignificant differences $(\mathrm{P}<0.05)$ among the rations of lactating goats which contained cellulolytic enzyme compared to the control ration. This finding may suggest the obtained results.

Alanin aminotransferase (ALT) of lactating goats received tested rations are shown in Table (5). There were insignificant differences among all groups in the overall means of serum ALT concentration. Kholif (2006) found that, animals fed on fibrolytic enzymes or fungi treated silage had no significant increase in serum ALT concentration. Such findings indicated that experimental animals were in good health.

Table (5): Effect of cellulolytic enzymes supplemented rations on some blood parameters of lactating goats.

\begin{tabular}{lccccc}
\hline \multirow{2}{*}{ Item } & \multicolumn{3}{c}{ Rations } & \multirow{2}{*}{ \pm SE } & \multirow{2}{*}{ Normal range } \\
\cline { 2 - 4 } & Control & $\mathrm{R} 1$ & $\mathrm{R} 2$ & & $10-50$ \\
\hline Urea, mg/dl & 30.67 & 32.33 & 34 & 0.71 & $0.7-1.5$ \\
Creatinine, mg/dl & 0.73 & 0.73 & 0.70 & 0.04 & $8-40$ \\
AST, U/dl & 32.44 & 31.86 & 32.38 & 2.39 & $5-30$ \\
ALT, U/dl & 26.33 & 24.36 & 25 & 1.15 & $48-76$ \\
Glucose, mg/dl & 68.25 & 69 & 71.67 & 3.57 & $65-136$ \\
Cholesterol, (mg/dl) & 67.33 & 69.33 & 68.67 & 2.40 & \\
\hline
\end{tabular}

Each value is mean of 3 samples

Serum glucose of lactating goats received the tested rations are shown in Table (5). There were insignificant differences among all groups in the overall means of serum glucose. These results are similar with those obtained by Kholif (2006) who found that animals fed on fibrolytic enzymes or fungi treated silage had no significant increase in serum glucose concentration. Farther, Azzaz et al. (2012) found that, cellulases addition to rations of lactating goats was not significantly affected plasma glucose concentration.

Serum total cholesterol of lactating goats received the tested rations are shown in Table (5). There were insignificant differences among all groups in the overall means of serum cholesterol and they within the normal range (65-136 mg dl) as stated by (Boyd, 2011). These results are similar with those obtained by Kholif et al.(2012), who found that, animals fed on fibrolytic enzymes had no significant effect in serum cholesterol

\section{Simple economical evaluation of the tested rations:}

The economical evaluation of the tested rations fed to lactating goats are presented in Table (6).The best net revenue (L.E/45d / head) was recorded for lactating goats fed ration supplemented with Asperozym (R1) followed by lactating goats fed control ration then lactating goats fed ration supplemented with Phytabex plus®. The cost of feed consumed for lactating goats fed ration supplemented with Phytabexplus ${ }^{\circledR}$ was higher than the other tested rations becauce of the price of commercial enzyme was higher. Azzaz (2009) found that, diets supplemented with cellulolytic enzymes economically better than control diet for feeding lactating zaraibi goats. The supriorety of R1 regarding net revenue may explain the lower cost of produced enzyme (Asperozym) compared to phytabex plus ${ }^{\circledR}$. 
Table (6): Simple economical evaluation of cellulolytic enzyme supplemented rations of lactatinggoats.

\begin{tabular}{llll}
\hline Item & \multicolumn{3}{c}{ Rations } \\
\cline { 2 - 4 } & Control & $\mathrm{R}_{1}$ & $\mathrm{R}_{2}$ \\
\hline Milk yield (kg/head/45d) & 15.27 & 17.33 & 16.80 \\
Dry matter consumed ( kg / head /45d ) & 33.44 & 34.02 & 34.04 \\
Price of one kg DM of the ration, L.E* & 2.08 & 2.28 & 2.48 \\
Cost of feed consumed (L.E / head / 45d ) & 69.56 & 77.57 & 84.42 \\
Total revenue, L.E* & 137.43 & 155.97 & 151.2 \\
Net revenue, L.E** & 67.87 & 78.4 & 66.78 \\
Relative percentage of net revenue & 100 & 115.5 & 98.39 \\
\hline
\end{tabular}

*, Total revenue, L.E = Milk yield $(\mathrm{kg}$ 45day) $\times 9.0$ L.E (price of one $\mathrm{kg}$ goats milk $($ L.E./h/45d)

**, Net revenue $($ L.E./h/45d) $=$ Total revenue $)$ - Cost of feed consumed $($ L.E. $/ \mathrm{h} / 45 d)$.Head

\section{REFERENCES}

Aboul-Fotouh G.E., G.M. El-Garhy, H.H. Azzaz, A.M. Abd El-Mola and G.A. Mousa (2016) .Fungal cellulase production optimization and its utilization in goat's rations degradation. Asian Journal of Animal and Veterinary Advances,Journal: 1683-9919 (11) Issue: 12, 824-831

A.O.A.C. (1995). Official Methods of Analysis of AOAC International, 16th Ed. Vol. 1, "Agricultural, Chemicals, Contaminants, Drugs". Washington, D.C., USA, 521p.

Azzaz, H.H. (2009). Effect of cellulytic enzymes addition to diets on the productive performance of lactating goats. M.Sc. Thesis, Fac. Agric., Cairo Univ., Egypt, 141 p.

Azzaz, H.H., Murad, H.A., Kholif, A.M., Hanafy, M.A., and Abdel Gawad, M.H. (2012). Utilization of cellulolytic enzymes to improve the nutritive value of banana wastes and performance of lactating goats. Asian J. Anim. \& Vet. Adv. 7: 664-673.

Ballard, C. S., Carter, M. P., Contach, K. W., Sniffen, C. J., Sato, T.K., Uchida, A. T., Nhan, U. D. and Meng, T. H. (2003). Feeding fibrolytic enzymes to enhance DM and nutrient digestion and milk production by dairy cows. J. Dairy Sci. 86:150.

Beauchemin, K. A., Yang, W. Z. and Rode, L. M. (1999). Effect of grain source and enzyme additive on site and extent of nutrients digestion in dairy cows. J. Dairy Sci., 82:378-390.

Bowman, G.R., Beauchemin, K.A. and Shelford, J.A (2002).The proportion of the diet to which fibrolytic enzymes are added affects nutrient digestion by lactating dairy cows. J. Dairy Sci., 85:3420-3429.

Boyd, J.W. (2011). The interpretation of serum biochemistry test results in domestic animal, In: Veterinary Clinical Pathology, Merck Sharp \&Dohme Corp., a subsidiary of Merck \& Co., Inc.

Burtis, C.A., Ashwood, E. and Bruns, D. (2006).Tietz Textbook of Clinical Chemistry and Molecular Diagnostics.4 thed, Elsevier saunders , 942-956.

Duncan, D.B. (1955). Multiple range and multiple F tests. Biometrics, 1:11.

Farag, M.A.A.M. (1979). Milk productions from local breeds of sheep.M.Sc .Thesis, Faculty of Agriculture, Zagazig University.

Gado, H.M., Salem, A.Z.M., Robinson, P.H. and Hassan, M(2009), Influence of exogenous enzymes on nutrient digestibility, extentofruminal fermentation as well as milk production and composition in dairy cows.Anim .Feed Sci .Technol;154:36-46.

Gaines, W. L. (1928). The energy basis of measuring energy milk in dairy cows. Univ. Illinois Agric.

Goering, H. K. and Van Soest, P. J. (1970). Forage Fiber Analysis (Apparatus, Reagents, Procedures and Some Applications). USDA. Agricultural handbook, Washington, DC, 379 p.

Howanitz, P.J. and Howantiz, J.H. (1984). In Clinical diagnosis and management by laporatory methods, 17thed. J.B. Henry, Ed, W.B.Saunders, Philadelphia, PP, 168. 
Khattab ,H.M., Gado, H.M., Kholif, A.E., Mansour, A.M. and Kholif, A.M . (2011). The potential of feeding goats sun dried rumen contents with or without $\mathrm{t}$ bacterial inoculums as replacement for berseem clover and the effects on milk production and animal health. Int. J. Dairy Sci., 6:267277.

Kholif, A.M., El-Ashry, M.A., El-Alamy, H.A., El-Sayed, H.M., Fadel, M. and Kholif, S.M. (2005). Biological treatments of banana wastes for feeding lactating goats. Egyptian J. Nutr. \& Feeds, 8:149162.

Kholif, S.M. (2006). Effect of improving the nutritional value poor quality roughages on the yield and composition of goat's milk. Egyptian J. Dairy Sci., 34:197-205.

Kholif, S.M., Gado, H., Morsy, T. A., El-Bordeny, N. and Abedo, A.A. (2012). Influence of exogenous enzymes on nutrient digestibility, blood composition, milk production and its composition as well as milk fatty acids profile in dairy buffaloes. Egyptian J. Nutr. \& Feeds, 15: 13-22.

Knowlton, K.F., Mc Kinney, J.M. and Cobb, C.(2002). Effect of adirect-fed fibrolytic enzyme formulation on nutrient intake, partitioning and excretion in early and late lactation Holstein cows. J.Dairy Sci., 85:3328-3335.

Morsy, T. A., Kholif,A .E ., Kholif, S .M ., Kholif, A.M., Sun, X. and Salem. A.Z.M. (2016). Effects of two enzyme feed additives on digestion and milk production in lactating Egyptian buffaloes. Ann. Anim. Sci., 16: 209-222.

Muwalla, M.M., Haddad, S.G. and Hijazeen, M.A. (2007). Effect of fibrolytic enzyme inclusion in high concentrate fattening diets on nutrient digestibility and growth performance of Awassi lambs. Liv. Sci., 111:255.

N.R.C. (1985). Nutrient requirement of sheep. National Academy of Science, National Research council. Ashington, D.C., USA.

Petera, A., Meyer, U. and Dänicke, S. (2015). Effect ofexogenousfibrolytic enzymes on performance and blood profile in early and mid-lactation Holstein cows. Anim. Nutr., 1: 229-238.

Reddish, M. A. and Kung, J. L. (2007). The effect of feeding a dry enzyme mixture with fibrolytic activity on the performance of lactating cows and digestibility of a diet for sheep.J. Dairy Sci. 90:4724-4729.

Reitman, S. and Frankel, S. (1957). A colorimetric method for the determination of serum glutamic oxalacetic and glutamic pyruvic transaminases. Am. J. Clin. Pathol, 28: 56-63.

Richard, A., McPherson, M.D., Matthew, R. and Pincus, M.D. (2011). Henry's Clinical Diagnosis and Measurement by Laboratory Methods, 22 nd., W.B. Saunders and Co., Philadelphia PA.p260.

Rodrigues, M.A.M., Pinto, P., Bezerra, R.M.F., Dias, A.A., Guedes, C.V.M., Cardoso, V.M.G., Cone, J.W., Ferreira, L.M.M., Colac, O. J.andSequeira, C.A. (2008). Effect of enzyme extracts isolated from white-rot fungi on chemical composition and in vitro digestibility of wheat straw. Anim. Feed Sci. Technol. 141, 326-338.

Salem, A. Z .M.,Elghandour, M.M.Y., Kholif, A . E., Odongo, N.E., Jiménez, F.J.P., Oca, R.M.D., Domínguez, I. A. and Dibarrat, J. A. (2015). The effect of feeding horses a high fiber diet with or without exogenous fibrolytic enzymes supplementation on nutrient digestion, blood chemistry, fecal coliform count, and in vitro fecal fermentation. J .Equine .Vet. Sci. (35) 735-74.

Sheppy, C. (2001). The current feed enzyme market and likely trends. Pages 1-10 in enzymes in farm animal nutrition. M. R. Bedford and G. G. Partridge, ed. CABI Publishing, Finn feeds Marlborough Wiltshire, UK.

Silva T. H ., Takiya ,C .S .,Vendramini ,T.H.A .,Jesus .E.F., Zanferari ,F. and Rennó, F.P.(2016). Effects of dietary fibrolytic enzymes on chewing time, ruminal fermentation, and performance of midlactating dairy cows. Anim. Feed Sci.Technol. PII: S0377-8401(16)30503-X.

SPSS. (2007). Statistical Package for Social Science, SPSS Inc., Chicago, IL, USA Copyright@ for Windows, version 16.0.

Upadhaya, S.D., Lee, S.I. and Kim, H. (2016).Effects of cellulase supplementation to corn soybean mealbased diet on the performance of sows and their piglets. Anim. Sci. J. 87, 904-910. 


\section{Egyptian J. Nutrition and Feeds (2017), 20 (2) Special Issue}

Valdes, K.I., Salem, A.Z.M., Lopez, S., Alonso, M.U., Rivero, N. and Elghandour, M.M.Y. (2015). Influence of exogenous enzymes in presence of Salix babylonica extract on digestibility, microbial protein synthesis and performance of lambs fed maize silage. J. Agric. Sci. Camb. i:10 .10 17 / S0 02 18- 59614000975.

Van Keulen, J.V .and Young, B.A. (1977). Evaluation of acid insoluble ash as a natural marker in ruminant digestibility studies. J. Anim. Sci., 44, 282.

Yang, W.Z., Beauchemin, K.A. and Rode, L.M. (1999). Effects of an enzyme feed additive on extent of digestion and milk production of lactating dairy cows. J. Dairy Sci., 82: 391-403.

\section{تأثير إستخدام بعض الإتزيمات المحلة للألياف فى العليقة على أداء الماعز الحلابة}

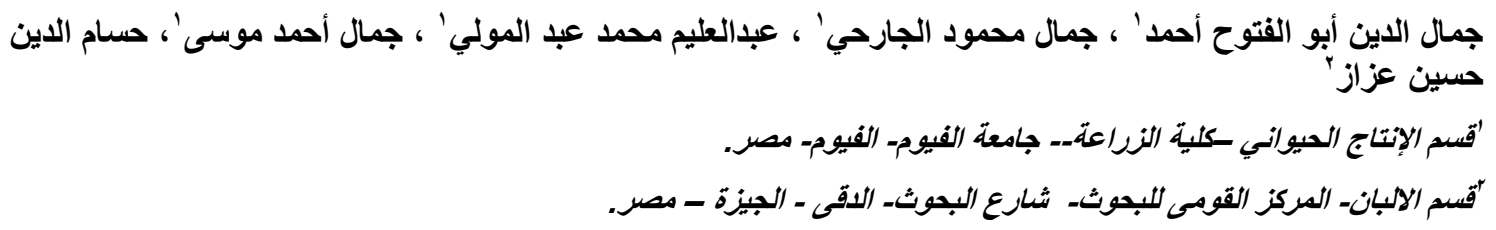

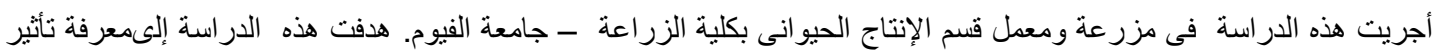

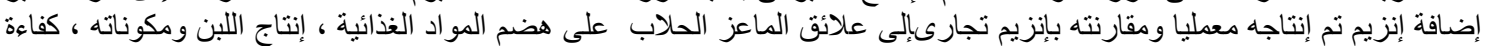

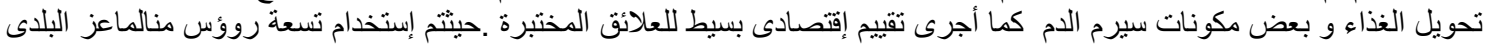

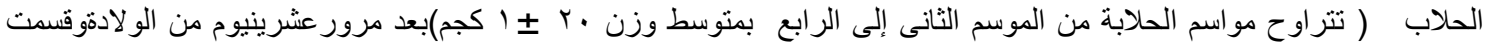

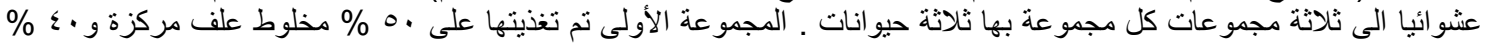

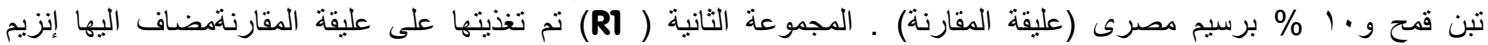

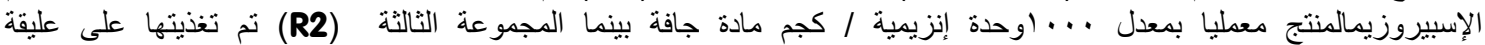

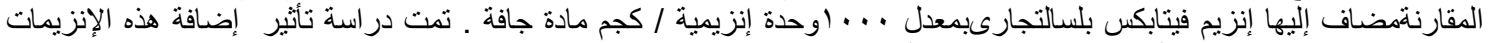

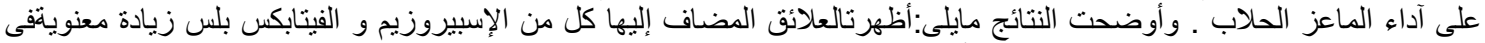

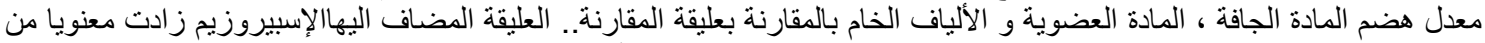

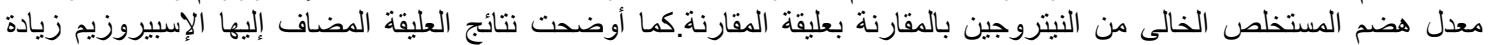

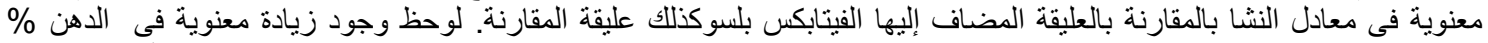

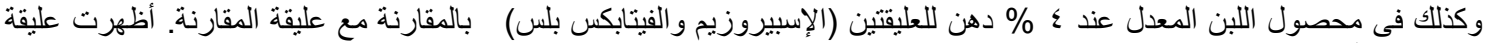

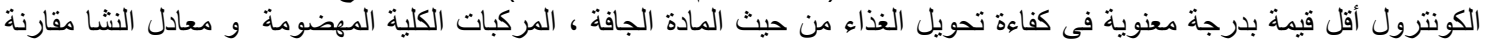
بعليقة الإسبيروزيم و عليقة الفيتابكس بلس ـ لوحظ عدم وجود إختلافات معنوية فى محتوى سيرم الدم بين جميع العلائق المختبرة لجميع

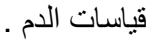

تحسنت القيمة الاقتصادية للماعز المغذى على العليقة المضاف لها الإسبيروزيمالمنتج محليا مقارنة بالماعز المغذى على العليقة المضاف لهاالفيتابكس بلسالتجارىوكذلك الماعز المغذى على عليقة المقارنة.

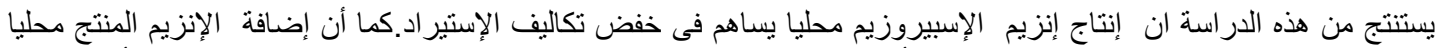

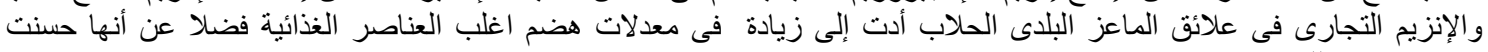
معنويامنإنتاج اللبن. 